Al-Uqud: Journal of Islamic Economics E-ISSN 2548-3544, P-ISSN 2549-0850 Accredited No. 28/E/KPT/2019
Volume 4 Issue 1, January 2020

DOI:10.26740/al-uqud.v4n1.p48-68

Page 48-68

\title{
Solution for Islamic Banks Exploitation: A Criticism of Fixed-Yields Based Financing in Indonesia
}

\author{
Muhamad Nafik Hadi Ryandono* \\ ${ }^{1}$ Department of Islamic Economics, Faculty of Economics and Business, Universitas \\ Airlangga. Jalan Airlangga 4, Surabaya 60286, Indonesia
}

Abstract: The profit-sharing system is the main characteristic of Islamic banking that distinguishes them from conventional (ribawi) banking. However, in reality, the profitsharing contract is rarely implemented in Islamic banking. As a result, Islamic banking is still identified as ribawi banking. Many Islamic economists have examined the reasons behind fixed income contracts, especially murabahah contract that applied predominantly, structurally, systematically and massively compared to the profit-sharing contract. Therefore, with a critical analytical approach, this study aims to dismantle and look for solution towards exploitation of fixed income-based financing in Indonesian sharia banking. The results of this study are fixed income-based financing should be applied limited to covering the operational costs of Islamic banks but the remainder must be channelled based on profit-sharing systems. Meanwhile, funding for profit-sharing systems is intended to gain profits and cover the operational cost variables. Thus, predatory exploitation of Islamic banks in Indonesia can be minimized by maintaining the composition of the maximum financing about forty per cent which is a fixed-yield based and leave the rest to a profit-sharing system. Then, the more equitable Islamic bank system and Islamic economic goals will be created and offer benefits such as the achieving of the objectives of Islamic sharia (maqashid shariah) and minimizing the image of Islamic banks as ribawi bank.

Keywords: Exploitation; Financing; Fixed yields; Predatory; Profit sharing.

Paper type: Research paper

*Corresponding author: muhammadnafik@ feb.unair.ac.id

Received: November 01, 2019; Accepted: January 13, 2020; Published: January 20, 2020

Cite this document: Ryandono, M. N. H. (2020). Solution for Islamic Banks Exploitation: A Criticism of Fixed-Yields Based Financing in Indonesia. Al-Uqud: Journal of Islamic Economics, 4(1), 48-68. doi: http://dx.doi.org/10.26740/al-uqud.v4n1.p48-68

Copyright (C) 2020, Al-Uqud: Journal of Islamic Economics http://journal.unesa.ac.id/index.php/jie 


\begin{abstract}
Abstrak: Sistem bagi hasil adalah karakteristik utama yang membedakan perbankan Islam dengan perbankan konvensional (ribawi). Namun, dalam kenyataannya, kontrak bagi hasil masih minim dilaksanakan di perbankan syariah. Akibatnya, perbankan syariah masih diidentikkan dengan perbankan ribawi. Banyak ekonom Islam telah meneliti alasan penggunaan pembiayaan berbasis imbal hasil tetap, terutama kontrak murabahah yang masih dominan, dan dipraktikkan secara terstruktur, sistematis serta masif dibandingkan kontrak bagi hasil. Oleh karena itu, dengan pendekatan analitis kritis, penelitian ini akan membongkar dan mencari solusi atas eksploitasi yang terjadi pada pembiayaan imbal hasil tetap di perbankan syariah Indonesia. Hasil penelitian ini adalah bahwa pembiayaan berbasis imbal hasil tetap hanya boleh digunakan secara terbatas untuk menutupi biaya operasional bank syariah dan sisanya harus disalurkan berdasarkan sistem bagi hasil. Pendanaan untuk sistem bagi hasil dimaksudkan untuk mendapatkan keuntungan dan menutupi biaya variabel operasional. Eksploitasi oleh bank syariah di Indonesia dapat diminimalisir dengan mempertahankan komposisi pembiayaan maksimum empat puluh persen yang merupakan imbal hasil tetap dan sisanya dengan sistem bagi hasil. Dengan demikian sistem bank syariah yang lebih adil dan menciptakan manfaat dengan pencapaian maqashid syariah akan lebih mudah dicapai dan citra bank syariah yang diidentifikasi dengan bank ribawi akan diminimalisir.
\end{abstract}

Kata kunci: Eksploitasi; Pembiayaan; Hasil tetap; Predator; Bagi hasil.

\title{
INTRODUCTION
}

The phenomenon of Islamic banking is considered to be contradictory to one of the main characteristics of Islamic finance, namely the principle of Profit and Loss Sharing which is carried out with shirkah (partnership) contract instruments (mudharabah and musyarakah). The shirkah contract is a reflection of justice in Islamic banking operations (Kusuma et al., 2018). Justice in profit-sharing practices can be seen mainly in the initial intention of Islamic banking that profit sharing is designed as the basis for compiling the banking system as a solution to the ribawi (containing riba or interest/usury) banking system. However, it is well known that Islamic banking financing is highly dependent on fixed yield-based instruments (murabahah, salam, istishna', qard and ijarah). It still become the dominant component in the Islamic bank financing. This condition, as well as other Islamic practices, if left unchecked, will trap Islamic bank in practices that does not adhere to Islamic principles (Kusuma, 2016).

Nevertheless, the condition of the Islamic bank is challenging because contract-based on fixed return have an economic impact but not much different from the banking system based on the ribawi system. If the financing of Islamic banks with the basis of fixed yield contracts used for productive financing such as buying and selling contract of raw materials for production and or with ijarah (leasing contract) of production equipment, the recipient of financing will get a surplus of income or income deficit.

Furthermore, if the recipient of the financing income is greater than the margin for the principle of sale and purchase, ujrah (fee) on the qard (loan) contract and the rental rate in ijarah, the recipient of the financing will gain a surplus. Nevertheless, if the income is lower than the margin, ujrah or rental rate, the recipient of the financing will be deficit. Surplus conditions may not be a problem 
for the customer or the bank, but when the customer's condition is a deficit, there is a predator and exploitation of the bank against the customer (Ryandono, 2018b).

Islamic banks toward fixed yield contract-has a small level of risk because the yield rate is relatively fixed and more controlled, but this is not for the customer. Thus, the Islamic bank will tend to choose a fixed yield-based contract in channelling its financing. This condition might harm the Islamic banking image that emphasizes the principle of justice in every operation because it does not prioritize justice but only the benefits and interests of the bank. This is relevant with the Islamic banking industry reports presented in the Islamic banking Statistics (SPS) issued by the Indonesian Financial Services Authority (OJK) as shown in Table 1.

Table 1. Financing Composition at Indonesia Islamic Banks Based on Contract 2014-2018

\begin{tabular}{cllllll}
\hline \multirow{2}{*}{ No } & Financing Contract & \multicolumn{5}{c}{ Financing Composition (\%) } \\
\cline { 3 - 7 } & & $\mathbf{2 0 1 4}$ & $\mathbf{2 0 1 5}$ & $\mathbf{2 0 1 6}$ & $\mathbf{2 0 1 7}$ & $\mathbf{2 0 1 8}$ \\
\hline 1 & Profit-Sharing (Variable yield) & 32.30 & 35.81 & 34.64 & 35.22 & 36.56 \\
2 & Fixed Yield & 64.52 & 64.19 & 65.36 & 64.78 & 63.44 \\
\hline
\end{tabular}

Source: Indonesian Islamic Banking Statistic 2014- 2018

Based on Table 1 above, it can be observed that the financing in Islamic banks in Indonesia until 2018 is still synonymous with fixed yield-based financing. Fixed yield-based financing contracts consist of murabahah, salam, istishna', qard and ijarah. Murabahah, salam, istishna', qard and ijarah are financing whose substance is a transaction contract which is not financing method of Islamic banks because it is a debt-based contract. Debt-based contract is mostly less relevant for long-term financing but only relevant for the short term. It is this debt -based receivable that creates Islamic bank image which has no different with an interest-based bank system. At the individual level, indebtedness creates vulnerability to exploitation or zulm (in Arabic) (Farooq et al., 2015). Meanwhile, slavery in the past often results from a vicious cycle of debt. In modern times, there is still widespread debt bondage and servitude in which consequences are similar to slavery (Allain, 2012). Rising debt-to-income ratios facilitated by aggressive marketing of consumer debt is not only create pressure to household budgets but also increase potential systemic risk (Geisst, C., et al 2010),

On the other hand, the fixed yield basis make the real economy has the same impact as the interest system if it is used for productive activities. Nevertheless, if it's for the consumptive financing, it will have a different impact from the interest system. The difference is that return financing has a fixed nature during the financing period while the interest will go up and down due to adjustments made by the bank without customer approval. The interest rate adjustment is applied for adjusting to the economic conditions and risks faced by the bank without considering the risks faced by the customer. When the economy deteriorates, the interest rate is raised and when the economy improves, the interest rate is lowered 
in consideration of adjusting the risks faced. This reflects the injustice and tyranny of the interest system.

The fixed-rate Islamic Bank financing contract is indeed simpler and easier to implement than the shirkah contract. The fact is supported by various arguments about difficulties and problems that arise in shirkah financing applications. The reason behind yields-based contract that continue to dominate Islamic bank financing has been approved at the Islamic banking conference held in Dubai in 1979 and also at the second Islamic banking Conference in Kuwait in 1983.

Moreover, the Islamic law forum in 1990, transactions of fixed return agreements are also accepted. This includes the fatwa issued by the National Sharia Council (DSN) of the Indonesian Ulema Council (MUI) regarding the use of murabaha (fixed yields) as financing contracts. However, various applications of fixed yield-based financing, especially murabahah in Islamic banking, have triggered a discussion related to its success. For example, executing a contract with a principal other than commodities, cutting the period of commodity ownership, buying the commodity from the client are the example by "buying back".

The previous researches about Islamic banks financing are discussed about the lack of Islamic banking in doing profit-sharing based contract and still dominating the fixed return contract like murabahah. Usmani, (2002), states that murabaha "... should not be used as a model of ideal Islamic financing or universal instruments for all types of financing. Murabahah should be used as a transitional step towards an ideal Islamic financing system based on musharaka or mudarabah." Henry et al., (2012), mentions massive use of murabaha as "murabaha syndrome." In countries other than Indonesia such as Malaysia, it is used as the term bay bi thaman 'ajil contract' (BBA/sales with installment payments). Bacha, (1995), indicates that with the use of instruments such as debt, Islamic banking will remain on the periphery of the financial world but is not in accordance with social needs. Whereas, Islamic banking is still need to concern with profit and also to aspects of benefits for the ummah (Herianingrum et all, 2017). As a business institution, Islamic banks are profit oriented, while as social institution Islamic banks are oriented to social benefits in order to solely seek the pleasure and to worship of Allah (Ryandono, 2018).

The question arises is why does this phenomenon occur in Islamic banking in general? Various reasons have been proposed as the dominant justification of fixed income yield-based contracts and the small portion of the use of sharing contracts in terms of funding and financing. Therefore, this study raises various arguments supported by previous studies. The first research question is why yield-based contracts remain inadequately implemented in Islamic banking based on economic analysis? Secondly, what is the solution of the predominance of fixed yield-based contracts in Islamic banking? Nevertheless, this study does not attempt to negate the existence of fixed yield-based contracts in Islamic banking, but to find a solution on how to treat fixed yield-based contracts in Islamic banking by not ignoring the pragmatic operation of Islamic banks so that Islamic banks are increasingly corrupt from time to time. This study is expected to solve the problem of the dominance of fixed income-based contracts in Islamic banking and will bring new insights in repairing the paradigm and practice of Islamic banks to stakeholders including 
Islamic banking industries, Indonesian financial service boards, also academics who are concerned in Islamic banking research.

\section{RESEARCH METHODS}

The focus of this study is the exploitation of the financing contract of the Islamic banking industry based on fixed-rate financing contracts and try to looking for solutions to this problem. The method used is a combination of comparative critical analysis and content analysis which are suitable to handle research in critical review phenomenon. Content analysis is used as analytical technique for making inferences that can be replicated from the valid data in context.

The research context is the contemporary economic community when the Islamic banking industry practices fixed yield-based financing contracts (murabahah, salam, istishna', qard and ijarah) juxtaposed with the conventional banking industry with the interest system. Content analysis is applied to seek the contents of data constancy. Yields remains in both the Islamic banking industry and the conventional banking industry in an economically practical manner will have the same economic impact even though the fixed yields in the Islamic banking industry are allowed by fiqh. Furthermore, this research tries to find solutions to the problems faced by the Islamic banking industry.

\section{RESULTS AND DISCUSSION}

\section{Islamic Bank}

Islamic banking in Indonesia is better known as Sharia bank. Islamic banking in Law No. 21 of 2008 concerning Islamic Banking Article 1 is "everything related to Islamic Banks (BUS) and Islamic Business Units (UUS), including institutions, business activities, as well as processes and processes in carrying out their business activities". Furthermore, an Islamic Bank is a bank that runs its business activities based on Islamic principles and according to its type consists of Islamic Commercial Banks and Islamic Public Financing Banks. Islamic Principle is the principle of Islamic Law in banking activities based on a fatwa issued by an institution that has the authority to establish a fatwa in the field of sharia (Islamic jurisprudence). The purpose of the sharia is to create maslahah with the achievement of maqashid sharia. It is a comprehensive and careful examination of the Shariah rulings entails an understanding that Shariah aims at protecting and preserving public interests (maslahah) in urgent aspects and segments of life (Kusuma, 2016). The intended Maqashid Sharia is protection of religion (addien), soul (an nafs), reason (al aql), descent (an nasl) and wealth (al maal) (Al Ghazali, 1983). Thus, the operation of Islamic Banks must always be based on these values.

Islamic banks in their business activities may adopt conventional banks, as long as they are not based on ribawi (containing riba or interest/usury) and must not violate Islamic laws for both Muslim and non-Muslim customers. Syahdeini (1999), says "Islamic banks may serve non-Muslim communities or be owned and managed by non-Muslims". Furthermore Syahdeini (1999), argues about the activities of Islamic banks namely; "Provide financial facilities by pursuing financial instruments based on sharia rules and norms. Islamic banking is not intended 
primarily to maximize profits as well as interest-based banking systems but to provide socio-economic benefits for Muslims."

Lewis (2007) argues that the main purpose of Islamic banking and finance is the elimination of usury from all financial transactions and all bank activities that imlement Islamic principles, fair distribution of income and wealth, and progress in economic development. Thus, if an Islamic bank cannot create prosperity (falah) both in the world and the hereafter for humanity, especially Muslims, Islamic banks can be categorized as having failed in carrying out their functions and roles in the economy. Mannan (1970), states that the general function of a Bank that uses sharia principles is providing ordinary public banking services, non-investment open account facilities, facilities to attract funds for investment in trade and business, social humanitarian services, and allowing withdrawal interest free and loans for special virtues (qardul hasan).

One of the ribawi systems is the interest system that forbidden in Islamic banks operation because practically, there is an injustice in the distribution of business income. As such, one party must receive income while the other party has no certainty in that income. Thus, the owner of the income certainty has made predatory and exploitation of parties who have not been certain to receive income. The predatory character and exploitation of the interest system can occur in Islamic bank operations, especially in fixed-rate financing contracts (murabahah, salam, istishna', qard and ijarah.) The five financing contracts cause a fixed burden for the recipient of financing, namely the burden of margin, ujrah and exploitation and predatory costs which increasingly evident when the five financings are used in business activities that have variable income but are not apparent if the business also has a fixed income. Exploitation and predatory practice occur when the recipient's income is lower than the margin level, ujrah and leases determined by the bank even though there will be a surplus if the income level is higher than the margin, ujrah and lease. Although the five contracts are obtained by fiqh, Islamic banks should always try to avoid them and if they continue to do so, it should be implemented in a limited composition to minimize exploitative characters and predatory ribawi systems.

\section{The Argument for Using a Funding Agreement Based on Fixed Yields on Islamic Banks}

Islamic bank's financing contracts based on fixed yields are more favoured and dominant in the Islamic banking industry than variable-yield instruments with profit-sharing models. Ascarya (2010) compiled a list of reasons for the lack of use of Profit-Sharing in Indonesia compared to the fixed returns by grouping them in two groups namely internal and external. The common internal problems are technical and managerial issues. Meanwhile, the basic external problems are the lack of commitment from the government and lack of trust between the communities itself. Moreover, Dar, H. and Presley (2000), enlist some reasons for the lack of use of the principle of profit-sharing in general. Some of the reasons are: production sharing contracts are very vulnerable to the agency, riskier, and require ownership rights that must be clearly defined and not feasible for short-term funding. Febianto \& Kasri (2012), also provide a list of reasons to explain why 
Islamic banking tends to avoid the Production Sharing contract because of a lack of transparency, high-cost supervision, and asymmetric information. Samad, A., et al, (2005), argues that the low use of Profit-Sharing in Malaysia and Bahrain is due to agency problems, ambiguity in terms of asset ownership, and investment constraints.

Bebczuk, (2003), revealed that the lack of use of participant sharing due to arising extra risks. In this context, the extra risks are asymmetric information and credit risk. Asymmetric information arises when the lender lacks of necessary information and lack of control over the ability of the recipient of the credit and their willingness to pay the debt. The most common form of asymmetric information is an adverse selection and moral hazard. Adverse selection occurs when the fund owner is unable to distinguish between projects with different credit risks when blocking credit. Moral hazard is the ability of users of funds to channeling funds that unsuitable with contract with the owner of the fund that held back by a lack of information and control over the borrower.

The Profit and Loss Sharing is fairer because the distribution of results reflects the business conditions that occur. Distribution of results will increase when the business results increase and vice versa will decrease if the business results also decline so that this model should be the main model of Islamic banks in collecting and channeling funds. Financing with the profit-sharing system will increase economic expansion by increase profits earned by the company and income of entrepreneurs, which in aggregate, rising incomes will boost the economy of expansion, in the form of rising investment, production, supply-demand, and reduce unemployment (Ryandono, 2009). Thus, this (profit-loss sharing) is what needed by the small micro-enterprise or startup companies in securing financial supports to their excellent business ideas (Hendratmi et al., 2019).

\section{Surplus and Exploitation of Contracts Based on Fixed Yields on Islamic Banks}

The Islamic Banking yield system is still dominated by fixed yield financing instruments and the low use of variable yield instruments, namely the profit-sharing system. Even by applying profit sharing combined with fixed yields, based some rules of sharia compliant, this model is still controversial. This condition makes Islamic banks not seen as being different from the ribawi bank. Why does this anomaly occurs in the practice of Islamic banks?: First, these things create a clash with idealism behind the affirmation of Islamic financial institutions.

Saeed (1998), argues that various initial studies of Islamic finance were based on idealism where the most "Islamic" and ideal forms of each concept would be accepted as valid. However, this idealism has been shifted towards pragmatism along with the development of Islamic finance in the last 50 years. Secondly, due to increased pragmatism, various sharia financial concepts are evaluated based on the form rather than their content. This is reflected in the effort to get approval from the sharia council for a product, service, etc. without questioning whether this is compatible with maqasid al shariah as the content of Islamic law. This promotes sharia compatibility from the application of Profit-Sharing in controversial Islamic banking. 
The shallowness of the difference between Islamic and conventional banking is strongly indicated when fixed yields, especially murabahah that used as financing instruments to shift profit sharing. In the case of yield-bearing financing, the crucial condition between Islamic banks and customers is the determination of the margin $\left(\mathrm{m}_{0}\right)$ of profit on financing objects with the principle of buying and selling (murabahah, salam and istishna') and ujrah on qard contract and rental costs in the ijarah contract. Why is it crucial? Because margins $\left(\mathrm{m}_{0}\right)$, ujrah $\left(\mathrm{u}_{0}\right)$ and rental costs $\left(\mathrm{s}_{0}\right)$ for Islamic banks are income so that the Islamic bank is very likely to want or offer these returns that are high on the financing. Whereas, returns for customers are costs then it is very possible customers want or offer low returns. The solution to this crucial problem is negotiating or bargaining, even though in reality the customer's position is weaker because of the conditions in need. The facts on the ground show that customers often do not have bargaining power or cannot bid margins $\left(\mathrm{m}_{0}\right)$, ujrah $\left(\mathrm{u}_{0}\right)$ and rental costs $\left(\mathrm{s}_{0}\right)$ or the price of the financing object. In other words, the customer only receives a yield or price determined by the Islamic bank. Therefore, the determination of the fixed rate of return if not careful will occur, namely exploitation and predation, especially by Islamic banks towards financing customers. Thus, even though fixed yield-based contracts are legally permissible, they will probably not be allowed and / or should be minimized in a limited amount because there will be harm and injustice when it implemented.

Margin $\left(\mathrm{m}_{0}\right)$, ujrah $\left(\mathrm{u}_{0}\right)$ and rental costs $\left(\mathrm{s}_{0}\right)$ are costs that must be borne by the customer. Buying and selling customers, qard and leases will cover these returns from the profit of producing purchased or leased assets or bailed out with funds obtained from the financing of buying and selling, qard and rent. Based on margins $\left(\mathrm{m}_{0}\right)$, ujrah $\left(\mathrm{u}_{0}\right)$ and rental costs $\left(\mathrm{s}_{0}\right)$ that borne by the customer, the level of business profits obtained by the customer in return for financing will still have two possibilities. First, the rate of profit obtained is greater than the margin $\left(\mathrm{m}_{0}\right)$, ujrah $\left(\mathrm{u}_{0}\right)$ and rent $\left(\mathrm{s}_{0}\right)$. In this condition, the customer will be able to cover the fixed yield burden and still have a surplus. Second, the level of profit obtained is smaller than margin $\left(\mathrm{m}_{0}\right)$, ujrah $\left(\mathrm{u}_{0}\right)$ and rent $\left(\mathrm{s}_{0}\right)$. In this second condition, the customer will not be able to cover the fixed yields and the customer will experience a deficit or loss. In this deficit condition, if it is not careful, there will be a process of exploitation and predatory Islamic banks towards the customer. The conditions of surplus and deficit (exploitation and predatory) on fixed yield-based financing can be graphically seen in Figure 1. 


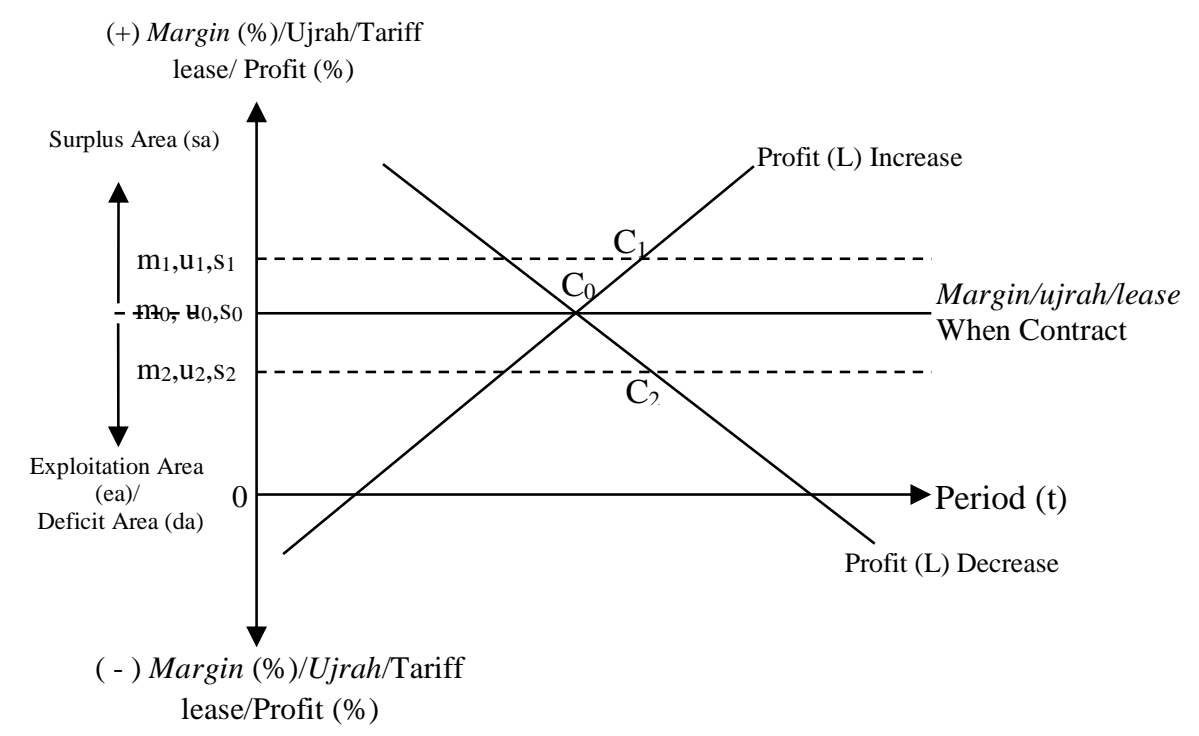

Figure 1. Surplus and Exploitation of Fixed Yield based Contract

Points $\left(\mathrm{m}_{0}\right),\left(\mathrm{u}_{0}\right)$ and $\left(\mathrm{s}_{0}\right)$ are large profit margin contracts under the principle of buying and selling, ujrah on qard contracts and rental rates in the ijarah contract when the contract is agreed (signed). Points $\left(\mathrm{m}_{1}\right),\left(\mathrm{u}_{1}\right)$ and $\left(\mathrm{s}_{1}\right)$ are the conditions of fixed returns raised $\left(\left(\mathrm{m}_{2}\right),\left(\mathrm{u}_{2}\right)\right.$ and $\left(\mathrm{s}_{2}\right)$ when the yield is still lowered by the Islamic bank. This condition occurs in general after a while the contract runs because of adjusting to the real economic conditions that occur. Margin $\left(\mathrm{m}_{0}\right)$, ujrah $\left(\mathrm{u}_{0}\right)$ and rental costs $\left(\mathrm{s}_{0}\right)$ in fiqh principle are permissible as long as it is fixed. Nevertheless, in reality, Islamic banks make adjustments to the reality of the economic conditions that occur. In deteriorating economic conditions the banks tend to raise the level of margin $\left(\mathrm{m}_{0}\right)$, ujrah $\left(\mathrm{u}_{0}\right)$ and rental costs $\left(\mathrm{s}_{0}\right)$ with reasons to cover the risks that might occur. If this is done, the yield has changed according to the interest system so that the bank will exploit the customer. Such conditions must be avoided by Islamic banks to maintain shariah compliance. Points $\mathrm{C}_{0}, \mathrm{C}_{1}$ and $\mathrm{C}_{2}$ are the critical points, namely the level of profit obtained can only cover the cost of margins $\left(\mathrm{m}_{0}\right)$, ujrah $\left(\mathrm{u}_{0}\right)$ and rent costs $\left(\mathrm{s}_{0}\right)$ or the point of Break-Even Point (BEP). At this critical point, the customer is not a surplus and also not a deficit, but the Islamic bank still receives a minimum return as long as the contract is signed. In other words, Islamic banks will continue to receive returns (income) in both surplus, deficit and BEP conditions.

Based on Fig. 1, it can be observed that the level of profit or profit (L) in the business has a positive possibility (profit) and negative (loss). The profit condition of a business whose assets are financed by fixed-yield-based contract financing from Islamic banks is a condition where the level of profit obtained is greater (higher) or increases beyond the margin $\left(\mathrm{m}_{0}\right)$, ujrah $\left(\mathrm{u}_{0}\right)$ and rent $\left(\mathrm{s}_{0}\right)$ determined (agreed) at the time of contract or in the surplus area (as). The surplus area (as) is the area where the level of profit $(\mathrm{L})$ is above the margin line $\left(\mathrm{m}_{0}\right)$, ujrah $\left(\mathrm{u}_{0}\right)$ and rent $\left(\mathrm{s}_{0}\right)$. Meanwhile, the loss condition for businesses whose assets are financed by fixed-yield financing from Islamic banks, is a condition where the level of profit 
obtained is smaller (lower) or decreases below the margin $\left(\mathrm{m}_{0}\right)$, ujrah $\left(\mathrm{u}_{0}\right)$ and rental costs $\left(\mathrm{s}_{0}\right)$ which is determined (agreed) at the time of the contract or the area of deficit (ad). The deficit area (ad) is the area where the level of profit (L) is below the margin line $\left(\mathrm{m}_{0}\right)$, ujrah $\left(\mathrm{u}_{0}\right)$ and rent $\left(\mathrm{s}_{0}\right)$. In this area, there will be a process of exploitation of financing customers. The surplus area (as), the area of exploitation (ae) and the area of deficit (ad) and the critical point $\left(\mathrm{C}_{0}, \mathrm{C}_{1}\right.$ and $\left.\mathrm{C}_{2}\right)$ will change if the Islamic bank changes the rate of return as an adjustment to the economic conditions that occur.

The surplus area (as) will decrease if the yield is increased and the impact is the area of exploitation will increase. Policies increase $\left(\mathrm{m}_{0}\right),\left(\mathrm{u}_{0}\right)$ and $\left(\mathrm{s}_{0}\right)$ to $\left(\mathrm{m}_{1}\right)$, $\left(\mathrm{u}_{1}\right)$ and $\left(\mathrm{s}_{1}\right)$ generally occur when economic conditions are deteriorating so that the condition of the customer gets worse or more exploited. In other conditions, the surplus area (as) will increase if the margin, ujrah and rental costs are lowered and the impact is that the exploitation area will decrease. The policy of reducing yields to $\left(\mathrm{m}_{2}\right),\left(\mathrm{u}_{2}\right)$ and $\left(\mathrm{s}_{2}\right)$ generally occurs when the economic conditions are improving so that the condition of the customers gets better or the surplus area increases. In this condition, if it is not carefully do, it is very possible to exploit the customer against the Islamic bank although the bank rarely decreases the yield rate due to the booming economic conditions.

Furthermore, when economic conditions deteriorate, Islamic banks tend to raise the yield rate with arguments to cover the possibility of risks that occur without regard to the risk of the customer. Therefore, if fixed income-based contracts are implemented in Islamic banks, although in permissible fiqh principle, if it is not carefully do, they will have predatory and exploitative characters and economic impacts similar to the interest system (usury). Therefore, it is better for Islamic banks to minimize the use of fixed income-based contracts, especially in their financing. It is because the determined rate of return does not reflect the customer's business conditions and actual economic conditions. To describe the actual economic conditions, Islamic banks always encourage their financing to use fixed yields on a limited basis or reduce their portion and increase the profit-sharing contract.

In this context, the use of fixed income based on Islamic bank financing is analogous to interest-based financing. This has become a phenomenon that exists in Islamic banking, that this short-term debt-based instrument is an attempt to duplicate the conventional banking model into Islamic banking. Some studies in previous literature (Farooq et al., 2015; Zubair et al., 2014; and Hanif, 2016) criticize Islamic banks that violating the sharia'h. For instance, Wilson, (2011), claims that products offered by Islamic banks are not different from those of conventional banks. Majeed, et al., (2018) research results added Islamic banks are not sharing risk. The reason behind it is Islamic banks are focusing on sale contract especially on murabahah and neglecting those financial contracts that offer risksharing. Even though the fact is that usury-based conventional banking has been destroyed by the economic crisis. Will do Islamic banking lead to destruction like conventional banking? Surely this is not expected. Therefore, this paper reveals the essence of the use of fixed-rate financing contracts that are similar to "Islamic usury." The use of fixed income-based contracts on Islamic banks makes bank 
income a fixed income similar to usury. This is contrary to the Quran, Luqman: 34 (Departemen Agama, 2010).

\section{Restrictions on Contracts Based on Fixed Yields only for Closing the Fixed Costs of Islamic Bank Operations}

The fixed-rate financing contract is not one of the traditional ways of financing such as the shirkah contract, but it is very popular in contemporary Islamic banking. The principle of buying and selling principle (murabahah, salam and istishna') is a contract of sale and purchase by adding value to the selling price that functions as profit/margin (mark-up profit), qard is giving debt which is generally a bailout to customers with ujrah as returns the result and ijarah for rent. This practice has become a phenomenon in Islamic banking and has become a debt-based short-term instrument. Critically, it can be said that this is an attempt to duplicate the conventional banking model into Islamic banking. Even though the fact is that conventional banking is based on usury. Whether then Islamic banking will also lead to destruction like conventional banking that is vulnerable to the economic crisis, do not occur the process of "Islamization of usury." Therefore, a mechanism is needed that serves as an effort to save not only the profitability of Islamic banking, but also enforce the main financial character Sharia through Islamic banking. In the context of Islamic banking, the use of a sale and purchase contract may be used, but to cover a bank's fixed operating expenses or practice in a limited amount.

Islamic banks in their operations are similar to companies in general. As a company, in addition to the income, it has various forms of costs. At least in this context, two cost models are used, namely fixed operational costs and variable operational costs, as well as fixed income and variable income. Fixed costs in Islamic banking are costs that must be incurred whose total amount remains within the range of changes in the volume of certain activities. The amount of the fixed costs is influenced by the company's long-term conditions, technology and management methods and strategies, such as investment in machinery purchases, depreciation, building construction, rental costs, employee salary costs and takaful, utility costs such as electricity, telephone, gas, etc. Variable costs are costs for which the total amount changes in proportion to the change in the volume of activity. Variable costs per unit are constant (fixed) with changes in the volume of activities.

Regarding income, the main Islamic banking income is obtained through financing. The focus of the discussion in this study is on buying and selling and profit-sharing. Sale and purchase financing is defined as murabahah while profitsharing as mudarabah. One of the fundamental differences between murabaha and mudarabah is in income. Murabahah has a fixed income characteristic while the mudarabah characteristics are variable (variable income).

In this context, the concept of limited fixed yields (restricted akad muqayadah) functions as an instrument to meet the fixed cost requirements issued by Islamic banks. Meanwhile, the cost variable is funded by profit-sharing which has the same nature that varies based on the income level that is known later. This 
is the basic philosophy of how to manage income and expenditure that both comparable.

The concept of fixed yield financing, in the sense of not on restrictions on the types of commodities transacted, but rather on the limitation of its use, namely the fixed yield financing that is allocated for fixed operational expenses. Revenue from this sale and purchase contract is fixed in every period (Fiafifah \& Darwanto, 2019).This is a middle ground to overcome the problems discussed in this study. This concept implies that the use of fixed yield financing will be limited to the number of transactions (portions) that are comparable to the fulfillment of the need for fixed operational expenses.

\section{Fair Composition (Exploitative Minimum Predatory) Islamic Bank Fixed} Return Financing

The composition of Permanent Yield Financing which can minimize exploitation on fixed yield contract-based financing (murabahah, istishna', salam, qard and ijarah) can be analyzed in 4 steps.

First Step: Calculate Proportional and Fixed Cost of Operational Financing (PFCOF). Proportional and Fixed Cost of Operational Financing (PFCOF) is calculated by comparing the amount of each Fixed Yield Financing (FYF) in this case is murabahah, Qard, istishna 'and ijarah with Total Fixed Yield Financing (TFYF) multiplied by the Total Fixed Operating Expenses (TFOE) or in a mathematical formula as follows:

Proportional and Fixed Cost of Operational Financing

$$
\begin{aligned}
& =\frac{\text { Fixed Yield Financing }}{\text { Total Fixed Yield Financing }} x \text { Total Fixed Operating Expenses } \\
\text { PFCOF } & =\frac{\text { FYF }}{\text { TFYF }} x \text { TFOE } \ldots \ldots \ldots \ldots \ldots \ldots \ldots \ldots \ldots \ldots \ldots \ldots \ldots \ldots \ldots \ldots \ldots \ldots \ldots \ldots \ldots \ldots \ldots \ldots
\end{aligned}
$$

For example, PFCOF murabahah yields in 2015 can be calculated by the formula (1) as follows:

$$
\begin{aligned}
& \text { PFCOF }=\frac{\text { Rp. 122.111, }-}{R p \cdot 137.463,-} x R p \cdot 10 \cdot 244,- \\
& \text { PFCOF }=\text { Rp. 9.1000,- }
\end{aligned}
$$

The full analysis can be seen in Appendix 1. 
Second Step: Calculate Fixed Yield Financing (FYF) to close Proportional Operation Cost (POC). Fixed Yields (FY) in question is the rate of return on fixed yield financing based on the yield rate agreed upon when the agreed-upon financing agreement is made. This FY calculated and is needed to be able to close the TFOE because the fixed expense must be closed from a fixed yield, namely FFY.

The FFY estimation method that can close the TFOE to be distributed is to divide FOEPF with the rate of Fixed Yields (FY) agreed upon in the FFY contract mathematically to be formulated as follows:

$$
\begin{aligned}
& \text { Fixed Yield Financing } \\
& =\frac{\text { Fixed Operational Expenses Proportional Financin }}{\text { Fixed Yields }} \times 100 \% \\
& F F Y=\frac{\text { FOEPF }}{F Y} \times 100 \%
\end{aligned}
$$

For example, FFY murabahah yields in 2015 can be calculated by the formula (2) as follows:

$$
F F Y=\frac{\text { Rp. } 9.100}{12,92} \times 100 \% \text {. }
$$

The full analysis can be observed in appendix 2 .

Third Step: Calculating Expectations for Operational Fixed Cost Financing Composition (EOFCFC). The expectation of Composition of Operational Fixed Coverage Financing (EOFCFC) is the amount of the composition of Financing of Fixed Yield (FFY) which is expected to generate income that can be used to cover Operational Fixed Costs (OFC). The method of calculating Operational Fixed Cost Financing Composition (OFCFFC) is by dividing the Fixed Yield Financing (FYF) closing the Total Fixed Operating Expenses (TFOE) with the total disbursed financing (based on a fixed income and variable income), mathematically can be calculated with the following formula:

$$
\begin{aligned}
& \text { Expectations for Operational Fixed Cost Financing Composition } \\
& =\frac{\text { Fixed Yield Financing Closing Total Fixed Operating Expenses }}{\text { Total financing }} \times 100 \%
\end{aligned}
$$

$$
\begin{aligned}
& \qquad E O F C F C= \\
& \frac{\text { FYF TFOE }}{\mathrm{TF}} X 100 \% \ldots \ldots \ldots \ldots \ldots \ldots \ldots \ldots \ldots \ldots \ldots \ldots \ldots \\
& \text { Examples of the calculation of the expectation } \\
& \text { cing of the fixed operating expenses of the bank, the } \\
& \text { s follows: } \\
& \text { EOFCFC }=\frac{\text { Rp. } 70.450,-}{\text { Rp. } 212.996,-} X 100 \%=33,08 \%
\end{aligned}
$$

Examples of the calculation of the expectation of the composition of the financing of the fixed operating expenses of the bank, the murabahah cases in 2015 are as follows:

The complete analysis can be seen in appendix 3 .

Based on the results of the analysis in appendix 3, we can calculate the intervals of the composition of fixed yield financing that able to minimize 
exploitation on fixed yield financing. First, calculate the standard deviation of the expected composition of fixed yield financing. The results produce a standard deviation of 2.06. Second, calculating the lower limit of the fixed yield financing composition, namely the expectation that the composition of the lowest fixed yield financing is reduced by the standard deviation, $(34.08-2.06=32.02$ rounded $32 \%)$. Third, calculating the upper limit of the expected fixed yield financing composition, namely the expectation of the composition of the lowest fixed yield financing plus the standard deviation, $(38.1+2.06=40.16$ rounded up to $40 \%)$. Thus, the level of composition of fixed yield financing, which the level of exploitation can still be neglected and can cover the operational fixed costs of Islamic banks in Indonesia in the 2015-2018 periods about 40 per cent. The composition is getting smaller than $40 \%$, the better (fair) because the exploitation is getting smaller and vice versa if the composition is getting bigger than $40 \%$, it is getting worse (unfair) because the exploitation is getting bigger.

Fourth Step: Calculating the Exploitation Rate of Fixed Yield Financing or Financing Composition Gap (FCG). The Financing Composition Gap (FCG) is the difference between the Real for Composition of Fixed-Yield Financing (RCFYF) and the Expectation for Composition of Real Fixed-Yield Financing (ECFYF) which expected to earn income to cover operational fixed costs. The level of the gap in the composition of fixed yield financing can be used to measure the level of exploitation of Islamic banks towards customers with fixed yield financing. The mathematical formula is as follows:

The Financing Composition Gap = Real for Composition of Fixed Yield Financing - Expectation for Composition of Real Fixed Yield Financing

$\mathrm{FCG}=\mathrm{RCFYF}-\mathrm{ECFYF}$

An example of a gap calculation of the composition of fixed yield financing with expectation that the composition of fixed yield financing in 2015 is known in the murabahah contract;

$$
\mathrm{FCG}=57,02 \%-33,08 \%=23,95 \%
$$

The full analysis can be seen in appendix 4.

Based on the results of the analysis in appendix 4, it can be observed that the average level of exploitation of Islamic banks in Indonesia in the 2015-2018 periods towards customers with fixed yield financing is an average of 28.28 percent. The bigger the gap shows the greater the exploitation. Conversely, if the gap is greater, the exploitation will increase. The factors that determine the size of the composition of the financing of fixed yields are the rate of return set or expected by the bank and operational efficiency. Therefore, these two factors will affect the level of exploitation of Islamic banks towards customers with fixed yield financing. The strategy of Islamic banks to reduce the level of exploitation is to maintain a fair 
level of the composition of financing for fixed yields but still enable income to cover the bank's fixed operating costs. Another strategy is to reduce the level of composition of fixed yield financing from time to time and increase the composition of variable yield financing (contract based on profit sharing or shirkah contract).

\section{CONCLUSION}

The phenomenon of excessive use of fixed yield contracts compared to the use of profit-sharing contracts in Islamic banking makes Islamic economic activists question the idealism of Islamic banking. It considers the principle of profit-sharing is the factor that distinguishes between Islamic banking and conventional banking. Excessive use of fixed yield financing requires Islamic banking to be the same as conventional banking. This study critically dissects how fixed-income financing in Islamic banking is practically an economy that has the same characteristics as usury. Ironically, Islamic banking makes fixed yield financing, especially murabahah, as the medium dominant, earning a maximum profit that has intentionally or unintentionally followed the conventional banking mindset. Limited fixed return financing (restricted fixed return) is an alternative solution to minimize exploitation in Islamic banking. Profits obtained from fixed return financing contracts should only be intended to cover fixed operational costs as well.

The level of composition of fixed yield financing, which the rate of exploitation can still be neglected, is because to cover the operational fixed costs of Islamic banks in Indonesia is a maximum of 40 percent. The smaller the composition is better because the exploitation is minimum. It considers yield financing that still has the characteristics of fixed income and philosophically, that between expenditure and income must be used in a comparable place. Hence, predatory and exploitation by Islamic banks towards customers of fixed yield financing can be minimized to create justice and Islamic banks will become effectively and practically different from conventional banks.

This general problem of Islamic banks financing has occurred in various countries in the world. Limitation of the study is this study only focus on Indonesia's Islamic bank's case. In the same general case, the basic solutions and calculation steps to find minimum fixed based contract rate (which has been proposed in this research) can also be applied in Islamic banking of other countries, although the indepth analysis is needed to be adjusted to these country's Islamic bank data that potential for the future research. 


\section{REFERENCES}

Agama, D. (2010). Al Quran dan Tafsirnya. Penerbit Lentera Abadi.

Al Ghazali, A. H. (1983). Al-Mustashfa fi'ilm al Ushul. al-Kutub al- Ilmiya.

Allain, J. (2012). Slavery in International Law: Of Human Exploitation and Traffic. Martinus Nijhoff Publishers. https://doi.org/10.1163/9789004235731

Ascarya. (2010). The lack of profit and loss sharing financing in Indonesia's Islamic banks: Revisited. Review of Indonesian Economic and Business Studies, 1(1), 57-80. http://www.iefpedia.com/english/wp-content/uploads/2009/09/THELACK-OF-PROFIT-AND-LOSS-SHARING-FINANCING-IN.pdf

Bacha, O. . (1995). Conventional versus Mudarabah Financing: An Agency Cost Perspective. IIUM Journal of Economics and Management, 4(2), 33-50. https://journals.iium.edu.my/enmjournal/index.php/enmj/article/view/27

Bebczuk, R. N. (2003). Asymmetric information in financial markets: Introduction and applications. Cambridge University Press. https://doi.org/10.1016/j.bar.2003.10.005

Dar, H. and Presley, J. R. (2000). Lack of Profit Loss Sharing in Islamic Banking : Management and Control Imbalances. International Journal of Islamic Financial Services. $\quad$ https://ekisopini.blogspot.com/2009/09/jualinternational-journal-of-islamic.html

Farooq, M. O., Farooq, M. O., \& Ahmed, A. (2015). Article information :

Febianto, I., \& Kasri, R. A. (2012). Why Do Islamic Banks Tend to Avoid Profit and Loss Sharing Arrangements? SSRN Electronic Journal. https://doi.org/10.2139/ssrn.1672127

Fiafifah, A. L., \& Darwanto, D. (2019). Technical Efficiency Level of Islamic Bank in Indonesia. Al-Uqud: Journal of Islamic Economics, 3(2), 114. https://doi.org/10.26740/al-uqud.v3n2.p114-132

Geisst, C., Goette, L. and Meier, S. (2010). Collateral Damaged: The Marketing of Consumer Debt to America. Bloomberg Press. https://doi.org/10.5860/choice.47-2113

Hanif, M. (2016). Economic substance or legal form: an evaluation of Islamic finance practice. International Journal of Islamic and Middle Eastern Finance and Management, 9(2), 277-295. https://doi.org/10.1108/IMEFM07-2014-0078

Hendratmi, A., Ryandono, M. N. H., \& Sukmaningrum, P. S. (2019). Developing Islamic crowdfunding website platform for startup companies in Indonesia. Journal of Islamic Marketing. https://doi.org/10.1108/JIMA-02-2019-0022

Henry, C., Wilson, R., \& Yousef, T. M. (2012). The Murabaha Syndrome in Islamic Finance: Laws, Institutions and Politics. In The Politics of Islamic Finance. https://doi.org/10.3366/edinburgh/9780748618361.003.0003

Herianingrum, Sri, et all. (2017). The Impact of Islamic Bank Financing on Business. Entrepreneurship and Sustainability Issues, 4(4), 133-145. https://doi.org/10.9770/jesi.2019.7.1(11)

Kusuma, K. A. (2016). Zakah index: Islamic economics' welfare measurement. Indonesian Journal of Islam and Muslim Societies, 6(2), 273-301. https://doi.org/10.18326/ijims.v6i2.273-301 
Kusuma, K. A., Santosa, N. E. T. I., Mursinto, D., \& Ryandono, M. N. H. (2018). Profit-sharing ratio determination of Mudharabah contract in Indonesia islamic banks. Opcion. https://www.researchgate.net/publication/331271239_Profit_Sharing_Ratio Determination_of_Mudharabah_Contract_in_Indonesia_Islamic_Banks

Lewis, M. K. \& L. M. A. (2007). Perbankan Syariah: Prinsip, Praktek dan Prospek (T. oleh B. Subrata (ed.)). PT Serambi Ilmu.

Majeed, M. T., \& Zainab, A. (2018). Sharia'h practice at Islamic banks in Pakistan. Journal of Islamic Accounting and Business Research, 9(3), 274-289. https://doi.org/10.1108/jiabr-03-2015-0011

Mannan, M. . (1970). Islamic Economics, Theory and Practice. The Islamic Foundation.

Ryandono, M. N. H. (2009). Bursa Efek dan Investasi Syariah. Serambi.

Ryandono, M. N. H. (2018a). Sukuk model determinant as funding strategy of Islamic Bank in Indonesia. Ijtihad: Jurnal Wacana Hukum Islam Dan Kemanusiaan, 18(2), 153. https://doi.org/10.18326/ijtihad.v18i2.153-174

Ryandono, M. N. H. (2018b). WAQF and Sukuk as economic financing sources in infrastructure development in Indonesia. Opcion, 34(86), 1699-1713.

Saeed, A. (1998). Idealism and pragmatism in Islamic banking: The application of shariah principles and adjustments. Journal of Arabic, Islamic and Middle Eastern Studies, 4(2), 89-111.

Samad, A., Gardner, N. D. and Cook, B. J. (2005). Islamic banking and finance in theory and practice: The experience of Malaysia and Bahrain. The American Journal of Islamic Social Science, 22(2), 69-86.

Syahdeini, S. R. (1999). Perbankan Islam dan Kedudukannya dalam Tata Hukum Perbankan Indonesia. Grafiti.

Usmani, M. T. (2002). An Introduction to Islamic Finance. The Hague, Kluwer Law International. In An Introduction to Islamic Finance. The Hague, Kluwer Law International.

Wilson, R. (2011). (n.d.). The Determinants of Islamic Financial Development and The Constraints on its Growth. 4th IFSB Lecture on Financial Policy and Stability.

Zubair, M., \& Choudhry, G. (2014). Islamic Banking in Pakistan: A Critical Review. International Journal of Humanities and Social Science, 4(2), 1-16. http://www.ijhssnet.com/view.php?u=http://www.ijhssnet.com/journals/Vol 4_No_2_Special_Issue January_2014/16.pdf 
Muhamad Nafik Hadi Ryandono: Solution for Islamic Banks Exploitation: $\mid 65$ A Criticism of Fixed-Yields Based Financing in Indonesia

Appendix 1. The Proportional Operational-Fixed Analysis with Fixed-Yield Financing 2015-2018

\begin{tabular}{|c|c|c|c|c|c|c|c|c|c|}
\hline \multirow[t]{2}{*}{ No } & \multirow{2}{*}{$\begin{array}{r}\text { Financing } \\
\text { Contract }\end{array}$} & \multicolumn{4}{|c|}{ Financing (Rp. Billion) } & \multicolumn{4}{|c|}{$\begin{array}{c}\text { Fixed Operational Expenses } \\
\text { Proportional Financing, FOEPF (Rp. } \\
\text { Billion) }\end{array}$} \\
\hline & & 2015 & 2016 & 2017 & 2018 & 2015 & 2016 & 2017 & 2018 \\
\hline 1 & Murabahah & 122.111 & 139.536 & 150.276 & 154.805 & 9.100 & 10.092 & 11.052 & 12.008 \\
\hline 2 & Istisha' & 770 & 878 & 1.189 & 1.609 & 57 & 64 & 87 & 125 \\
\hline 3 & Salam & 0 & 0 & 0 & 0 & 0 & 0 & 0 & 0 \\
\hline 4 & Ijarah & 10.631 & 9.230 & 9.230 & 10.597 & 792 & 668 & 679 & 822 \\
\hline 5 & Qard & 3.951 & 4.731 & 6.349 & 7.674 & 294 & 342 & 467 & 595 \\
\hline \multicolumn{2}{|c|}{$\begin{array}{l}\text { Total Fixed Yield } \\
\text { Financing (TFYF) }\end{array}$} & 137.463 & 154.375 & 167.044 & 174.685 & & & & \\
\hline \multicolumn{2}{|c|}{$\begin{array}{l}\text { Total Fixed } \\
\text { Operational } \\
\text { Expenses (TFOE) }\end{array}$} & 10.244 & 11.165 & 12.285 & 13.550 & 10.244 & 11.165 & 12.285 & 13.550 \\
\hline
\end{tabular}

Source: Indonesian Islamic Banking Statistic 2015- 2018, process

The results of the proportional operational fixed cost financing analysis are used for analysis in the second step. 
66 Al-Uqud: Journal of Islamic Economics

Volume 4 Issue 1, January 2020

Appendix 2. Analysis of Fixed-Yield Financing for Closing BTO

\begin{tabular}{|c|c|c|c|c|c|c|c|c|c|c|c|c|c|}
\hline \multirow{2}{*}{ No } & \multirow{2}{*}{$\begin{array}{l}\text { Financing } \\
\text { Contract }\end{array}$} & \multicolumn{4}{|c|}{$\begin{array}{l}\text { Proportional Fixed Cost of } \\
\text { Financing (PFCF), Rp. Billion }\end{array}$} & \multicolumn{4}{|c|}{$\begin{array}{c}\text { Fixed-Rate of Yields (FFY) } \\
(\%)\end{array}$} & \multicolumn{4}{|c|}{$\begin{array}{c}\text { Financing with Closing Yields, FCY } \\
\text { (Rp. Billion) }\end{array}$} \\
\hline & & 2015 & 2016 & 2017 & 2018 & 2015 & 2016 & 2017 & 2018 & 2015 & 2016 & 2017 & 2018 \\
\hline 1 & Murabahah & 9.100 & 10.092 & 11.052 & 12.008 & 12,92 & 11,95 & 12,72 & 13,03 & 70.450 & 84.428 & 86.886 & 92.189 \\
\hline 2 & Istisha' & 57 & 64 & 87 & 125 & 11,95 & 12,07 & 10,09 & 9,51 & 480 & 526 & 866 & 1,313 \\
\hline 3 & Salam & 0 & 0 & 0 & 0 & 0 & 0 & 0 & 0 & 0 & 0 & 0 & 0 \\
\hline 4 & Ijarah & 792 & 668 & 679 & 822 & 11,45 & 13,35 & 12,20 & 10,04 & 6.921 & 5.001 & 5.564 & 8.187 \\
\hline 5 & Qard & 294 & 342 & 467 & 595 & 9,44 & 8,69 & 8,00 & 8,01 & 3.119 & 3.939 & 5.836 & 7.428 \\
\hline & $\begin{array}{l}\text { tal Fixed } \\
\text { erational } \\
\text { penses (TFOE) }\end{array}$ & 10.244 & 11.165 & 12.285 & 13.550 & & & & & 80.969 & 93.893 & 99.152 & 109.115 \\
\hline
\end{tabular}

Source: Indonesian Islamic Banking Statistic 2015- 2018, process

The results of the analysis of fixed yield financing to cover the bank's fixed operating expenses in table are the input of analysis in the third step. 
Appendix 3. Analysis of Expectation of Financing Composition Closes Fixed Operational Expenses

\begin{tabular}{|c|c|c|c|c|c|c|c|c|c|}
\hline \multirow[t]{2}{*}{ No. } & \multirow{2}{*}{$\begin{array}{l}\text { Financing } \\
\text { Contract }\end{array}$} & \multicolumn{4}{|c|}{$\begin{array}{l}\text { Fixed Yield Financing (FYF) Closing TFOE } \\
\text { (Rp. Milyar) }\end{array}$} & \multicolumn{4}{|c|}{$\begin{array}{c}\text { Expectations for Operational Fixed } \\
\text { Cost Financing Composition } \\
\text { (EOFCFC), \% }\end{array}$} \\
\hline & & 2015 & 2016 & 2017 & 2018 & 2015 & 2016 & 2017 & 2018 \\
\hline 1 & Murabahah & 70.450 & 84.428 & 86.886 & 92.189 & 33,08 & 34,04 & 30,41 & 28,79 \\
\hline 2 & Istisha' & 480 & 526 & 866 & 1.313 & 0,23 & 0,21 & 0,30 & 0,41 \\
\hline 3 & Salam & 0 & 0 & 0 & 0 & 0 & 0 & 0 & 0 \\
\hline 4 & Ijarah & 6.921 & 5.001 & 5.564 & 8.187 & 3,25 & 2,02 & 1,95 & 2,56 \\
\hline 5 & Qard & 3.119 & 3.939 & 5.836 & 7.428 & 1,46 & 1,59 & 2,04 & 2,32 \\
\hline \multicolumn{2}{|c|}{ Total Financing (TF) } & 212.996 & 248.007 & 285.695 & 320.193 & & & & \\
\hline $\begin{array}{l}\text { The } \\
\text { Fixe } \\
\text { Fina } \\
\text { Com } \\
\text { (EFI }\end{array}$ & $\begin{array}{l}\text { Pectation of } \\
\text { Yield } \\
\text { cing } \\
\text { osition } \\
\text { FC) }\end{array}$ & & & & & 38,1 & 37,86 & 34,71 & 34,08 \\
\hline
\end{tabular}

Source: Indonesian Islamic Banking Statistic 2015- 2018, process

The results of the calculation of the expected composition of fixed yield financing can be used to calculate the gap in the composition of real, expected returns on financing and the level of exploitation of fixed-rate financing Islamic banks. The gap analysis of composition or level of exploitation can be seen in step four. 


\section{Appendix 3. Financing Composition Gap (FCG) Analysis}

\begin{tabular}{|c|c|c|c|c|c|c|c|c|c|c|c|c|c|c|}
\hline \multirow[t]{2}{*}{ No } & \multirow[t]{2}{*}{$\begin{array}{c}\text { Financing } \\
\text { Contract }\end{array}$} & \multicolumn{4}{|c|}{$\begin{array}{c}\text { Real for Composition of } \\
\text { Fixed Yield Financing } \\
\text { (RCFYF), \% }\end{array}$} & \multicolumn{4}{|c|}{$\begin{array}{l}\text { The expectation for } \\
\text { Composition of Real } \\
\text { Fixed Yield Financing } \\
\text { (ECFYF), \% }\end{array}$} & \multicolumn{4}{|c|}{ Real Gap with Hope (\%) } & \multirow[t]{2}{*}{ Average } \\
\hline & & 2015 & 2016 & 2017 & 2018 & 2015 & 2016 & 2017 & 2018 & 2015 & 2016 & 2017 & 2018 & \\
\hline 1 & Murabahah & 57,02 & 59,08 & 58,28 & 56,22 & 33,08 & 34,04 & 30,41 & 28,79 & 23,95 & 25,04 & 27,87 & 27,43 & 26,07 \\
\hline 2 & Istisha' & 0,36 & 0,37 & 0,46 & 0,58 & 0,23 & 0,21 & 0,30 & 0,41 & 0,13 & 0,16 & 0,16 & 0,17 & 0,16 \\
\hline 3 & Salam & 0 & 0 & 0 & 0 & 0 & 0 & 0 & 0 & 0 & 0 & 0 & 0 & 0 \\
\hline 4 & Ijarah & 4,96 & 3,91 & 3,58 & 3,85 & 3,25 & 2,02 & 1,95 & 2,56 & 1,72 & 1,89 & 1,63 & 1,29 & 1,63 \\
\hline 5 & Qard & 1,84 & 2,00 & 2,46 & 2,79 & 1,46 & 1,59 & 2,04 & 2,32 & 0,38 & 0,41 & 0,42 & 0,47 & 0,42 \\
\hline $\begin{array}{l}\text { Tot } \\
\text { Fin: }\end{array}$ & $\begin{array}{l}\text { Fixed Yield } \\
\text { acing }\end{array}$ & 64,19 & 65,36 & 64,78 & 63,44 & 38,01 & 37,86 & 34,71 & 34,08 & 26,18 & 27,50 & 30,07 & 29,36 & 28,28 \\
\hline
\end{tabular}

Source: Indonesian Islamic Banking Statistic 2015- 2018, process 